Federal Reserve Bank of Minneapolis

\title{
QuarterlyReview
}

Summer 1983

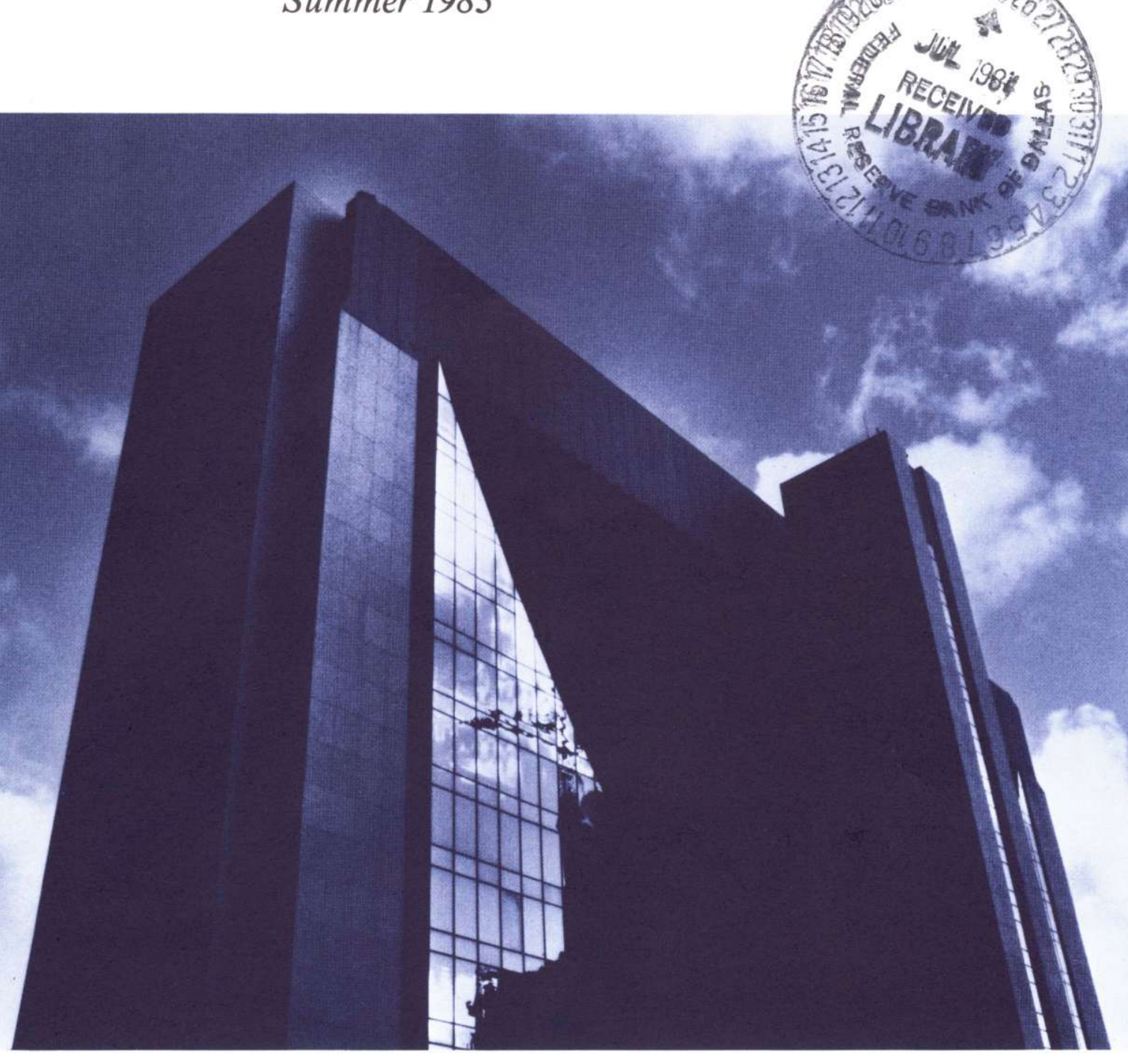

Toward a More Resilient International Financial System Anthony M. Solomon (p. 2)

A Primer on the International Monetary Fund 
Federal Reserve Bank of Minneapolis

Quarterly Review vol.7, No. 3 ISSN 0271-5287

This publication primarily presents economic research aimed at improving policymaking by the Federal Reserve System and other governmental authorities.

Produced in the Research Department. Edited by Richard M. Todd.

Graphic design by Phil Swenson and typesetting by Barbara Cahlander and Terri Desormey, Graphic Services Department.

Address requests for additional copies to the Research Department,

Federal Reserve Bank, Minneapolis, Minnesota 55480.

Articles may be reprinted if the source is credited and the Research

Department is provided with copies of reprints.

The views expressed herein are those of the authors and not necessarily those of the Federal Reserve Bank of Minneapolis or the Federal Reserve System. 


\section{Toward a More Resilient International Financial System*}

Anthony M. Solomon

President

Federal Reserve Bank of New York

I feel certain that a great many of you here tonight-and, in fact, thoughtful people throughout the business and financial community - have been following the twists and turns of the debt problems of the world's less-developed countries (LDCs) extremely closely over the past year or so. The press and other media have provided extensive coverage. And there have been several excellent analyses of how the debt problems came about, both in general and for individual countries. Overall, I conclude that public understanding of the current situation is unusually good, given the enormous complexity of the issues at stake.

What I think is less familiar, and worthy of more attention, is the discussion of what the world will be like after the current emergency is behind us. We all want to feel confident that, when something closer to normal circumstances is restored, we will have built a stronger, more resilient international financial system. No one wants a recurrence of debt disturbances like those of the past year. No one wants prolonged stagnation or inadequate growth in the developing countries of Latin America and elsewhere. That would worsen our own growth prospects and inhibit world trade. And prolonged stagnation-as distinct from the temporary setbacks associated with emergency adjustment programs - would raise a greater danger of serious social and political consequences in a number of the LDCs.

\section{Managing the Current Debt Problems}

Before discussing the postemergency period, I must make clear that I'm not complacent about the immediate task of completing the necessary debt restructurings and carrying through basic economic adjustments. We have to make sure we sustain the kind of concerted effort by all the principal participants which has yielded the tentative progress that's been made so far. The borrowing countries, the commercial banks, the governments in the industrial countries, and the International Monetary Fund (IMF) have all had to make tough decisions and hard compromises. In particular, I think we should respect the painful measures that have already been taken and the sacrifices that have been endured by Mexico and some other countries. Under IMF guidance, these countries have, by any reasonable standard, made impressive efforts to adjust. But more hard work and political will must be marshalled, and more new financing will be required, before anyone can afford to relax.

Obviously, this concerted effort must go forward and must succeed. But make no mistake about it. That can't happen unless the IMF can continue to play the pivotal role it has in binding together the different parts of this effort. And the Fund will be unable to play that role if it's starved of adequate financial resources and political support.

Frankly, I find it baffling that there are elements in this country, and especially in our Congress, who can ignore the catastrophic effects that would result from not acting now to make resources available to the IMF quickly. Without the IMF at the pivot, the whole debt restructuring effort would be undermined, and needed new credits would be blocked. Outright defaults could actually happen. In the longer run, the consequences could also be grave. Debtor countries could be forced into disorderly adjustments that would almost certainly include more

*Remarks made September 20, 1983, before the Economic Club of New York. Edited for publication at the Federal Reserve Bank of New York. 
protectionist measures, credit controls, price distortions, and severe damage to local private sectors. It would injure the world trading system and seriously impair the prospects for economic growth, not only in the debtor countries but here and everywhere else.

The direct cost to the United States alone would be enormous. Until last year, our exports to LDCs that now have debt servicing problems had been averaging $\$ 50$ billion a year-almost a quarter of our total exports. Already last year, exports to these countries fell by over $\$ 10$ billion (more than 20 percent), costing us nearly 300 thousand jobs and $\$ 1$ billion in profits. How can it be rational for this country to risk giant price tags like these in the future and oppose an increase in funding for the IMF (the quota increase)?

I know that there are those who don't see it this way. Some look at the issue entirely in narrow financial terms and conclude that the IMF can squeak by without the quota increase for the time being. That view is wrong, and it misses the central point. In the absence of clear, unequivocal support for the institution by the U.S. government, including the Congress, the Fund will be permanently crippled.

What's even more baffling is that, among those who would cripple the Fund, there are people who claim to be strong advocates of free markets. What they entirely fail to see is that the IMF, in its efforts to get countries to pursue market-oriented policies and to minimize the hodgepodge of distortions that undermine economic performance, is the best friend that market-oriented people have in the kind of world we live in.

My strong sense is that the misguided opposition to the IMF quota legislation, and the mischievous amendments that undercut it, will not prevail. I believe that ultimately the Congress will support the IMF and act positively to meet the international responsibilities of the United States. It is in both our immediate and longer-term interest.

\section{Coping With Continuing Constraints}

Suppose that we all do what we need to do in the short term. Then, it's worth raising the question of what kind of economic prospects the LDCs-especially in Latin America, where the debt burden is greatest-can look forward to in a couple of years, when the immediate emergency is behind, but not forgotten. Can they return to rates of economic growth that are reasonably satisfactory and broadly meet their aspirations for achieving social and political progress? I don't want to put specific numbers on this, because growth potential differs from one country to the next. But I am talking about growth rates that would not be too far below the historical experience of most of the countries before the debt problems materialized.

It seems to me that it is certainly not impossible to get that outcome. But we have to face reality. There are going to be continuing constraints that will limit the scope for expansionary policies for some time to come. We can identify ways of easing some of these constraints and softening their impact. And we can be heartened by more optimistic developments lately in the industrial economies, where the prospects for higher growth seem to be improving. But there still must be an extended period in which the heavily indebted LDC governments are going to have very little margin for error.

The most obvious constraint will be with respect to external financing. Conventional commercial bank lending will be much harder to come by. In the first instance, that would limit countries' ability to import. And lower imports, particularly of capital goods, will hamper growth.

The natural question is whether that shortfall can be replaced by greater official assistance from industrial country governments. In my view, that is not likely. While government officials have the will and resources to provide temporary support in a crisis, there really isn't much chance of legislatures going along with increases in long-term official funding in amounts large enough to significantly offset lower commercial bank lending. After all, it was partly because of the difficulty of obtaining official financing that borrowing from banks grew so much in the first place.

Another question is whether the central banks of industrial countries-in particular, the Federal Reserve-should provide large-scale infusions of liquidity so as to ease credit availability for LDCs. Certainly, in a crisis, central banks have a traditional responsibility, as lenders of last resort, to insure stability. But any assistance of that sort must be strictly temporary. Central banks simply cannot be viewed as a source of mediumand long-term financing.

So what's left? By the process of elimination, there are really only two alternatives: Either funds will have to find their way into LDCs through channels other than commercial banks, or borrowing countries will have to run their economies in ways that make them less dependent on external financing. In fact, the LDCs will have to move 
on both fronts at the same time if they hope to be able to achieve the satisfactory growth rates we are talking about.

\section{Alternative Funding Channels}

Traditionally, direct investment has been an alternative to bank financing. In calmer times, greater direct investment inflows should be an effective source of capital. To be sure, we know that the internal political opposition to direct investment has been strident from time to time in the past and certainly could resurface as soon as the debt emergency starts to fade. Yet, it seems to me that this manifestation of economic nationalism must be challenged and overcome if the LDCs are going to be serious about economic development in a period when new borrowing from commercial banks is constrained.

Improving financial management offers another important way for borrowing countries to cope with the constraints they are going to face. This should especially include efforts to diversify the currency composition of a country's debt. By choice or by necessity, too much of the debt of many LDCs was in dollars. That left them vulnerable to a period of high dollar exchange rates and high dollar interest rates. We calculate that if from 1979 to 1982 developing countries had borrowed currencies in a diversified way - that is, in proportion to their import shares - the LDCs as a group would today be over \$30 billion better off. I am not saying that kind of benefit can be repeated in any particular time period in the future. But the clear lesson is that a more balanced and skillfully drawn portfolio of debt is important. Of course, that requires not only a willingness of borrowers to diversify, but equally a willingness of market participants to modify their operations and of the authorities in other industrial countries to allow it.

In addition, both borrowers and lenders have an interest in taking some potentially valuable financial instruments off the drawing board and getting them to market. To take one example, perhaps commercial banks could shift at the margin toward originating loans and then selling them off into a secondary market, where price fluctuations could give useful, early disciplinary signals to borrowers. Or, to take another example, I can visualize variable maturity obligations that offer a constant debt service flow in the face of any unexpected jump in interest rates, a kind of built-in rescheduling. There may also be a place in the market for securities with equitylike features, on which some part of the total yield to the investor could be calibrated, for instance, to the borrowing country's real gross national product or export earnings growth or some similar measure of economic performance.

Finally, there are a number of tools and techniques that are used by corporate borrowers here but are not yet being used by borrowers in developing countries. Just to give two illustrations, these instruments range from futures contracts to hedge against commodity fluctuations to interest rate swaps that can add another way of gaining fixed rate funding. In a period of restricted access to credit, it is worthwhile developing the expertise and sophistication to take advantage of the array of novel financing tools that are now available.

\section{Economic Policy Reforms}

Innovations like those in the private capital markets would be helpful in ameliorating the financing problem. But I wouldn't want to overstate the role that these mechanisms can play. It will not eliminate the need for major changes and reforms in general economic policies so that dependence on external financing is lastingly reduced.

The way I see it there are three broad areas where policy, reform in borrowing countries is called for to reduce dependence on external financing and promote domestic savings. (After all, on average, gross domestic savings finance 90 percent of LDC investment.)

The first is in the balance of payments area. It seems to me that heavily indebted developing countries have to be resolute in keeping their exports competitive in world markets. First and foremost, this means following realistic exchange rate policies and not letting the domestic currency get out of line. It also means realistic interest rates to deter damaging flight of domestic capital.

The second broad area is reform of government budgeting. To begin with, though it's getting harder for an American to preach to others on the subject, excessively large structural deficits have to be reduced. In addition, LDC governments must have tighter oversight of spending agencies, closer financial monitoring of projects, better and more timely budget numbers, and improved regulatory capabilities over their own financial institutions.

The third broad area is reform of the domestic price system. Every subsidy, every credit allocation scheme, every price distortion has to be tested against the standard of what it costs, both in budgetary terms and in terms of economic efficiency. These are long-standing problems that existed well before the debt crisis. And fixing any of them inevitably pits a government against powerful 
vested interests at home. But in the aftermath of the debt problem, there may be no alternative to meeting the task head-on, because of the huge toll distortions take in limiting productivity and growth.

\section{Help From the Rest of the World}

The governments in the industrial countries and the IMF both have to support LDC efforts to bring about marketoriented reforms and better financial management.

The industrial countries obviously have a major role to play in sustaining growth, in lowering global interest rates by reducing their own government deficits, and in keeping markets open for LDC goods. At the same time they have to open up their financial markets further so that the LDCs can diversify their sources of credit more effectively. They must help create a healthy world environment within which the LDC efforts can pay off.

As for the IMF, its role in managing crises is wellrecognized and indispensable. But treatment and cure are not enough; it must work harder and more effectively at prevention. What I see as close to being essential is that its surveillance role under more normal circumstances be enhanced. This has two dimensions.

First, the IMF should be assisting countries in improving their financial management. It can help them monitor their debts. It can work with countries to develop financial strategies covering the currency and maturity mix of borrowing as well as the degree of reliance on bank debt, bond finance, direct investment, and so on.

Second, appropriate IMF surveillance should extend well beyond matters of finance. The Fund is not just a lender. It is a force for promoting sensible policies. I believe it should put its weight behind governments which are committed to a transition toward more efficient domestic price, interest rate, and exchange rate policies. And it must reject the argument that the IMF should focus only on a balance of payments target, regardless of how it's achieved.

These broader efforts by the Fund should be an integral part of its regular consultations with all members. We don't want to go back to a situation where the IMF becomes deeply involved only after serious payments disruptions have occurred. That's too late.

Instead, a more continuous relationship would have some important advantages. It would improve the Fund's detailed knowledge of the constraints that regularly confront policymakers in each individual country. And it would provide a type of involvement by the Fund that might head off some of the resentment and occasional hostility that can occur when the IMF is seen as an outsider always prescribing austerity at a time of trouble.

To encourage movement in this general direction, I would go even one step further. It would be worthwhile considering whether access to funding could be made more readily available by the IMF to countries that voluntarily participate in these financial and economic policy reviews, should they have a balance of payments need later on.

\section{Summary}

In summary, we must plan for a world of tighter financial constraints and less margin for error. The approach I am recommending boils down to a combination of stronger market institutions and better market instruments developing alongside better economic policies and stronger financial controls. In my approach, there is no quick fix. There is no single scheme or gimmick that will put things right and allow everybody to go back to business as usual. To the contrary, I feel that those debt reshuffling schemes that you hear about, which look to industrial country governments to pick up existing exposure from the banking system, are fanciful. They would be unjustifiably costly to the taxpayers. And in fact, they would give just the wrong signals, convincing people at home that a government bailout will always be there and whipping up pressures abroad in developing countries to ask for bailouts.

What I am recommending is rooted instead in pragmatism. It basically seeks to build a more resilient system on the best features of what we have now.

And what we have now pivots on the IMF. That is the institution which in practical terms binds the system together and which must play a more comprehensive role in the future. Therefore, the first step toward that kind of system is for the Congress to act quickly and positively on the IMF quota legislation and put to rest doubts about the commitment of the United States to a commonsense, multilateral approach to dealing with the world's financial problems. 